\title{
Identification of myocardial extracellular matrix expansion by cardiac MRI in hypertensive patients
}

\author{
Francois-Pierre Mongeon*, Michael Jerosch-Herold, Otavio Rizzi Coelho-Filho, Luciana F Seabra, Eri Watanabe, \\ Ron Blankstein, Raymond Y Kwong
}

From 2011 SCMR/Euro CMR Joint Scientific Sessions

Nice, France. 3-6 February 2011

\section{Background}

Left ventricular hypertrophy (LVH) is an important marker of adverse prognosis in cardiovascular disease and commonly occurs in association with hypertension. While late gadolinium enhancement (LGE) reflects myocardial replacement fibrosis in hypertensive patients, we hypothesized that the myocardial extracellular volume fraction (MECVF) would better reflect the presence and severity of myocardial fibrosis, including diffuse fibrosis, in hypertensive patients with LVH. We sought to measure the MECVF directly using T1 imaging pre- and post-contrast.

\section{Methods}

We performed 3T cardiac MRI in 19 subjects including 9 normo-tensive control subjects (mean age $45 \pm 11$ years, $66.7 \%$ female) and 10 patients (mean age $65 \pm 15$ years, $40 \%$ female) with (1) systemic hypertension, (2) LVH by ECG or echocardiography, (3) a LVEF $\geq 50 \%$ and (4) no LGE. MRI included cine imaging and LGE 10 minutes after $0.15 \mathrm{mmol} / \mathrm{Kg}$ of gadolinium. In addition, a Look-Locker gradient echo technique with adiabatic inversion was used, once before and 3 times over a 30min period after gadolinium injection, to quantify T1. The myocardial partition coefficient was estimated by least-squares linear regression of R1 (1/T1) in myocardium against R1 in blood. MECVF was obtained by adjusting the partition coefficient by the patient's hematocrit.

\section{Results}

The mean blood pressure (BP) at the time of MRI was not significantly different in treated hypertensive patients compared with control subjects (mean systolic BP 128 vs. $118 \mathrm{mmHg}, \mathrm{p}=0.1165$; mean diastolic BP 69 vs. $74 \mathrm{mmHg}, \mathrm{p}=0.2930$ ). Despite the presence of LVH by ECG or echocardiography, the median LV mass index by cardiac MRI only demonstrated a trend increase $(\mathrm{p}=0.0653)$ in hypertensive patients $\left(53.8 \mathrm{~g} / \mathrm{m}^{2}\right.$ IQR 41.3-59.2) compared to controls $\left(44.5 \mathrm{~g} / \mathrm{m}^{2}\right.$ IQR 36.5-48.3). However, there was evidence of increased

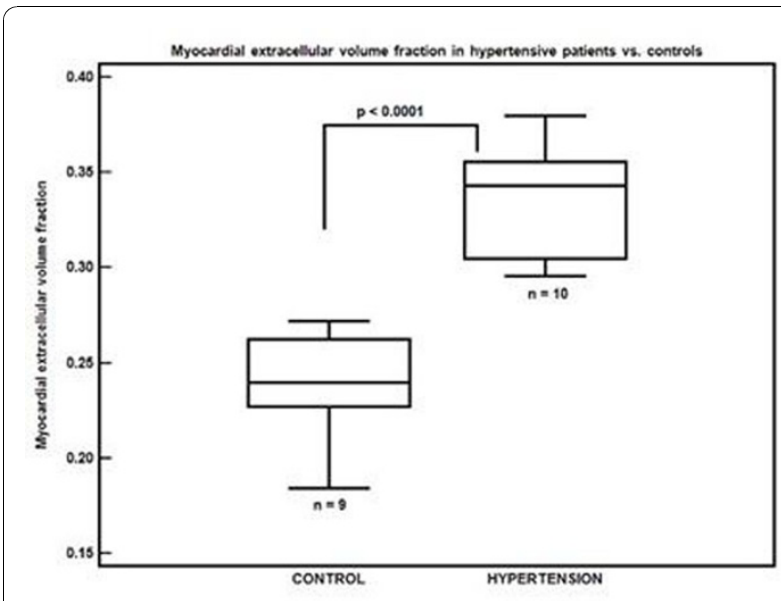

Figure 1

Brigham and Women's Hospital, Boston, MA, USA

(c) 2011 Mongeon et al; licensee BioMed Central Ltd. This is an open access article distributed under the terms of the Creative 
MECVF in hypertensive patients (mean $0.34 \pm 0.03$ vs. $0.24 \pm 0.03$ in controls, $\mathrm{p}<0.0001$, figure). There was no correlation between MECVF and LV mass index $(\mathrm{r}=0.32, \mathrm{p}=0.17)$, and between MECVF and the $\mathrm{E} / \mathrm{E}^{\prime}$ ratio by tissue Doppler echocardiography in hypertensive patients $(\mathrm{n}=8, \mathrm{r}=0.24 \mathrm{p}=0.53$ for the lateral wall, $\mathrm{r}=0.12 \mathrm{p}=0.75$ for the septal wall).

\section{Conclusions}

Patients with chronic hypertension show evidence of extracellular matrix expansion. We postulate that our method of direct quantification of extracellular matrix expansion by MECVF may better reflect the impact of increased afterload on the LV myocardium than LV mass or echocardiographic assessment of diastolic function. This novel quantitative method also holds promises for monitoring the effects of antihypertensive medication.

Published: 2 February 2011

doi:10.1186/1532-429X-13-S1-0109

Cite this article as: Mongeon et al:: Identification of myocardial extracellular matrix expansion by cardiac MRI in hypertensive patients. Journal of Cardiovascular Magnetic Resonance 2011 13(Suppl 1):0109.
Submit your next manuscript to BioMed Central and take full advantage of:

- Convenient online submission

- Thorough peer review

- No space constraints or color figure charges

- Immediate publication on acceptance

- Inclusion in PubMed, CAS, Scopus and Google Scholar

- Research which is freely available for redistribution

Submit your manuscript at www.biomedcentral.com/submit
C Biomed Central 